\title{
The ICF in the pedagogical projects of Physiotherapy courses in Midwest Brazil
}

\section{A CIF nos projetos pedagógicos dos cursos de Fisioterapia do Centro-Oeste brasileiro}

\author{
Juliana Aparecida Elias Fernandes (1D]a], Marília Miranda Forte Gomes (1D[b,c], \\ Bruna da Silva Sousa [D] [b], Juliana de Faria Fracon e Romão [i] [a], Diana Lúcia Moura Pinho [i] \\ Vera Regina Fernandes da Silva Marães [i] $[\mathrm{a}, \mathrm{b}] *$
}

[a] Universidade de Brasília (UnB), Ceilândia, DF, Brasil

[b] Universidade de Brasília (UnB), Gama, DF, Brasil

[c] Universidade de Brasília (UnB), Brasília, DF, Brasil

\begin{abstract}
Introduction: The course pedagogical projects (CPPs) of physical therapy programs in Brazil are based on National Curriculum Guidelines for Physiotherapy (NCGP) and the principles of the National Health System (SUS). The CPPs that guide professional training tend to use a biopsychosocial approach and propose familiarizing undergraduate students with the International Classification of Functionality, Disability and Health (ICF); as such, they should include the use of this instrument. Objective: Assess CPPs by exploratory document analysis and determine whether they propose teaching and using the ICF in student training. Method: Qualitative-quantitative study with document analysis of CPPs for physical therapy courses in Midwest Brazil, from which information related to the ICF was extracted. Results: The biopsychosocial model and NGCP were identified in the 10 CPPs analyzed and the ICF was found in the curriculum outline of 6 of these,
\end{abstract}

*JAEF: Doctoral student, email: julianaeliasunb@gmail.com

MMFG: PhD, email: mariliamfg@gmail.com

BSS: MS, email: bruzinhadolly27@gmail.com

JFFR: PhD, email: julianafracon@gmail.com

DLMP: PhD, email: mourapinhodl@gmail.com

VRFSM: PhD, email: vrmaraes@gmail.com 
indicating the incorporation of this framework in student training. However, the ICF was only identified in the course objectives and literature references of 4 and 2 CPPs, respectively, suggesting possible shortcomings in its application in these documents. Conclusion: The inclusion of the ICF in some CPPs indicates a positive change and favors understanding of functioning, but does not preclude the need for a broader approach to teaching this classification framework in the remaining CPPs in order to provide student training within a biopsychosocial context.

Keywords: ICF. Physical Therapy. Curriculum. Teaching.

\section{Resumo}

Introdução: Os projetos políticos pedagógicos dos cursos de Fisioterapia (PPCs) no Brasil são concebidos à luz das Diretrizes Curriculares Nacionais do Curso de Graduação em Fisioterapia (DCNF) e aos princípios do SUS. Assim, os PPCs que norteiam a formação profissional tendem a incluir uma proposta de familiarização dos graduandos com a Classificação Internacional de Funcionalidade, Incapacidade e Saúde (CIF) com uma abordagem biopsicossocial, portanto os PPCs deveriam contemplar o uso da CIF. Objetivo: Verificar, por meio da análise exploratória dos PPCs, se existem propostas de ensino e uso da CIF na formação dos alunos. Método: Estudo quali-quantitativo, realizado por meio da análise documental exploratória dos PPCs dos cursos de Fisioterapia do Centro Oeste Brasileiro, dos quais foram extraídas informações de interesse relacionadas à CIF.

Resultados: $O$ modelo biopsicossocial e o delineamento das DCNF foram identificados nos 10 PPCs analisados e a CIF foi encontrada na matriz curricular de 6 PPCs, o que aponta positivamente para incorporação da CIF no processo formativo do aluno. Entretanto, somente em 4 PPCs foi possível identificá-la nos objetivos do curso e nas referências bibliográficas de disciplinas obrigatórias, a CIF foi encontrada em apenas 2 PPCs, o que pode indicar nesses documentos, uma possível fragilidade da abordagem da CIF. Conclusão: A presença da CIF em alguns PPCs indica mudanças e favorece o entendimento da funcionalidade, o que não anula a necessidade de uma maior abordagem quanto ao ensino da CIF nos demais PPCs, visando a formação do aluno dentro de um contexto biopsicossocial.

Palavras-chave: CIF. Fisioterapia. Currículo. Ensino.

\section{Introduction}

The industrial revolution and two world wars in the 18th and 20th centuries, respectively, were major milestones in the advent of physical therapy [1]. This was reinforced by the polio epidemic in the United States from 1916 to 1955 [2] and, in Brazil, in the 1950s [3, 4], peaking in Rio de Janeiro [5]. This panorama certainly contributed to establishing physical therapy as a science, given the increased demand from people with disabilities, and to technicity, since practices were based on Cartesian-like impairment of the body. Thus, the psychological, environmental or social impacts were not considered, strengthening practices based on a biomedical model [6 - 9].

Physical therapy was initially a technical profession and higher education institutions in the states of Rio de Janeiro, São Paulo and Minas Gerais subsequently began to offer undergraduate courses in the field [4, $10,11]$. Since then, it has spread nationwide [12], but to date, the Southeast still has the highest concentration of physiotherapy courses in the country $[13,14]$.

Regulations for the profession were implemented in 1963 via Ordinance 388 of the Ministry of Education and Culture (MEC), which placed physical therapy under the auspices of the medical profession [15]. This generated significant repercussions in terms of the pursuit of greater autonomy and professional esteem [4], which culminated in important class movements. In 1969, then Brazilian president Artur da Costa e Silva suffered a stroke, which also increased the prominence of physiotherapy as a profession [12]. Decree-Law no. 938/69 finally legitimized physical theory, recognizing it as a higher education-level profession $[16,17]$, with 
the subsequent creation of the Federal (COFFITO) and Regional Boards of Physical Therapy and Occupational Therapy (CREFITOs) further reinforcing its autonomy and credibility [18].

The creation of the Brazilian National Health System (SUs) in the 1980s broadened the concept of health. This new focus prompted important reflections on professional training, with courses governed by "minimalist curricula" [12] in order to move away from professional practices that separate the general overview from the individual as a whole and the illness [19 - 24], leading to the creation of National Curriculum Guidelines for Physiotherapy (NCGP) [25].

The NCGP guide course pedagogical projects (CPPs) within the broader concept of health and highlight the role of physical therapists in the SUS [26]. It is important to underscore the contrast between this broad concept and the decree that legitimized the profession, where excerpts such as "...with the purpose of restoring, developing and preserving the physical capacity of clients" [16] refer to the biomedical model, since only biological factors seemed to be considered.

However, by targeting a more generalist and humanized approach at all levels of complexity [25], the professional profile proposed by the NCGP is the equivalent of complete separation between the body and mind, internal and external, physical and psychic [20], making it difficult to answer important questions in the disease process when the focus is on health (and not illness), according to the biopsychosocial model.

Conceptually, this model encompasses biological, social, environmental and personal dimensions [27, 28], clarifying processes related to physical disability and function. Physical disabilities are impairments that limit activities and restrict social participation, whereas functioning is understood as the healthy interaction between an individual's biological functions, activity and social participation [27, 29]. As such, the shift in perception of the health-disease process and the new professional profile proposed by NCGP encompass the concept of functioning, since its dimensions go beyond purely biological issues.

In this respect, the International Classification of Functioning, Disability and Health (ICF) classifies health and health-related domains [30], providing new insights on the field [31] and representing a milestone in physical therapy in that it recognizes disease as multifactorial, environmental and attitudinal $[27,31]$, which enables interdisciplinary and multi-professional practices [32]. As opposed to following a rigid linear model, the ICF is a clinical and pedagogical tool for research, statistics and social policies [27, 28,31,33], directly in line with the SUS and NCGP.

It was officially endorsed by the 54th World Health Assembly (WHA 54.21) [34] and in Brazil, by Resolution $370 / 2009$ of COFFITO [35], which stipulated the use of the ICF by physical and occupational therapists. Application of the ICF within the SUS is supported by National Health Council (CNS) Resolution 452 of 2012 [36]. In light of these changes in professional practices, it is important to assess and adjust the content of CPPs to the principles of the SUS and application of the ICF, given that the education and training of physical therapists will directly affect professional practice [37]. As such, this study aimed to assess CPPs by document analysis and determine whether they propose teaching and using the ICF in student training in undergraduate physical therapy courses in Midwest Brazil.

\section{Method}

This was a qualitative-quantitative study that used exploratory analysis of the CPPs of physical therapy courses in Midwest Brazil, represented by the Federal District (DF) and the states of Goiás (GO), Mato Grosso (MT) and Mato Grosso do Sul (MS).

Document analysis, a fundamental technique in human and social science research [38,39], is increasingly being used to address complex problems such as those in the field of health $[40,41]$. It improves understanding of the phenomena of interest by expressing the contents of documents in a simpler manner and involves characterizing the documents, coding content, constructing categories, recording data and critical analysis [42].

The different stages of methodological construction are described below:

Stage 1: Identifying physical therapy courses in Midwest Brazil

This phase was carried out from May to June 2018, using the Ministry of Education database (e-MEC) as the official and only source of information on higher education courses in Brazil, focusing on the Midwest. The CPPs were selected based on the following inclusion criteria: the course grade (CG), a quality rating issued by the Ministry of Education after an on-site assessment by the Anísio Teixeira National Institute 
of Educational Studies and Research (INEP/MEC). The CG is a grade from 1 to 5 , where 1 is the lowest quality and 5 the highest. The CPPs of courses that were still operational and received a CG of 3 or more at their most recent assessment (INEP/MEC) were analyzed in this study. Those that did not meet these criteria were excluded.

\section{Stage 2: Access to the CPPs}

The CPPs were initially researched on the institutional websites and, when available in full, saved as PDF files to be read later. Otherwise, access to the CPPs was requested by email from the course coordinators.

Stage 3: Compiling the instrument for CPP analysis

For the purposes of document analysis, an instrument (guiding script) was compiled to help extract data on the biopsychosocial model as well as the teaching and use of the ICF in undergraduate courses. Two researchers experienced in teaching and applying the ICF tested, adjusted and defined the guiding questions of the study and their categories, based on the parameters below:

a) The NCGP, which contribute to the quality of CPPs and should be used by all physical therapy courses to provide quality training for students and equip them to work in the SUS [25]. A study published by the Ministry of Education also contributed to the methodological design of our investigation since it cites alignment between the profile of graduates and national curriculum guidelines (NCG), among other aspects [43]. The guiding questions established were: Is the graduate profile in line with NCGP? Is the discourse of the CPP in accordance with the biopsychosocial model? Based on these, the following categories were defined:

- Graduate profile in line with NCGP

- CPP based on the biopsychosocial model

b) Resolution 370/2009 (COFFITO), which stipulates use of the ICF by physical and occupational therapists and teaching the instrument in undergraduate courses [35], and National Health Council Resolution 452 of 2012, which implemented the ICF in the SUS [36], were the foundation for the following questions: Does the "Course Objectives" section of the CPP include the ICF? Does the "Curriculum Outline" section of the CPP include required courses that address the ICF?

Do the literature references of required courses include the ICF?

- The ICF in the course objectives

- The ICF in the curriculum outline of required courses

- The ICF in the literature references of required courses

After content analysis of the CPPs [44 - 46], all the categories described here were allocated an answer of "yes" or "no" [47].

\section{Stage 4: Document analysis}

The CPPs were read independently and in full by the two researchers, following the same guiding script and categories. This was done from August to December 2018 and the data extracted were tabulated in Word for subsequent comparison. The CPPs were numbered from 1 to 10 to ensure the confidentiality of the courses studied, separated by state/ Federative Unit and respectively identified as CPP 1, CPP 2, CPP 3... CPP 10.

The researchers used established strategies to answer "yes" or "no" to each category listed in Table 1, as follows:

Table 1 - Categories and strategies used by the researchers to answer "yes" or "no"

\begin{tabular}{ll}
\hline Category & \multicolumn{1}{c}{ Strategy } \\
\hline $\begin{array}{l}\text { ICF in the course } \\
\text { objectives }\end{array}$ & $\begin{array}{l}\text { Assess whether the course } \\
\text { objectives include the term ICF or } \\
\text { functioning either literally or in a } \\
\text { contextualized format }\end{array}$ \\
$\begin{array}{l}\text { Graduate profile in line } \\
\text { with NCGP }\end{array}$ & $\begin{array}{l}\text { Assess whether the profile of } \\
\text { graduates is in line with NCGP. }\end{array}$ \\
$\begin{array}{l}\text { ICF in the curriculum } \\
\text { outline of required } \\
\text { courses }\end{array}$ & $\begin{array}{l}\text { Determine whether the curriculum } \\
\text { ICF in the literature } \\
\text { references of required } \\
\text { courses }\end{array}$ \\
$\begin{array}{l}\text { Evaline of courses contains the ICF. } \\
\text { references of required courses. }\end{array}$ \\
$\begin{array}{l}\text { Observe whether NCGP are taken } \\
\text { into account in the biopsychosocial }\end{array}$ \\
$\begin{array}{l}\text { aspect of the CPP, indicating } \\
\text { skills and competences that go } \\
\text { beyond the biological sphere and } \\
\text { include elements related to ethical, } \\
\text { environmental and psychological } \\
\text { dimensions. Additionally, check if } \\
\text { the CPP contains the actual term } \\
\text { "biopsychosocial" and its context }\end{array}$ \\
biopsychosocial model
\end{tabular}


Stage 5: Data analysis

After the qualitative data obtained by each researcher were extracted and organized, their notes and perceptions while reading the CPPs were transcribed. Quantitative data were the year of the CPP, whether the institution was public or private, course grade (CG), minimum class hours, total number of semesters and number of annual places available. These were analyzed using descriptive measures in Statistical Package for the Social Sciences software, version 20.0 (SPSS 20.0).

\section{Results}

Figure 1 shows the flowchart of the selection process for physical therapy courses and their respective CPPs. According to the MEC database, in 2018 there were 82 courses in Midwest Brazil, only 52 of which were still operational at the time of this study; after application of the inclusion criteria, 10 CPPs were selected and analyzed.

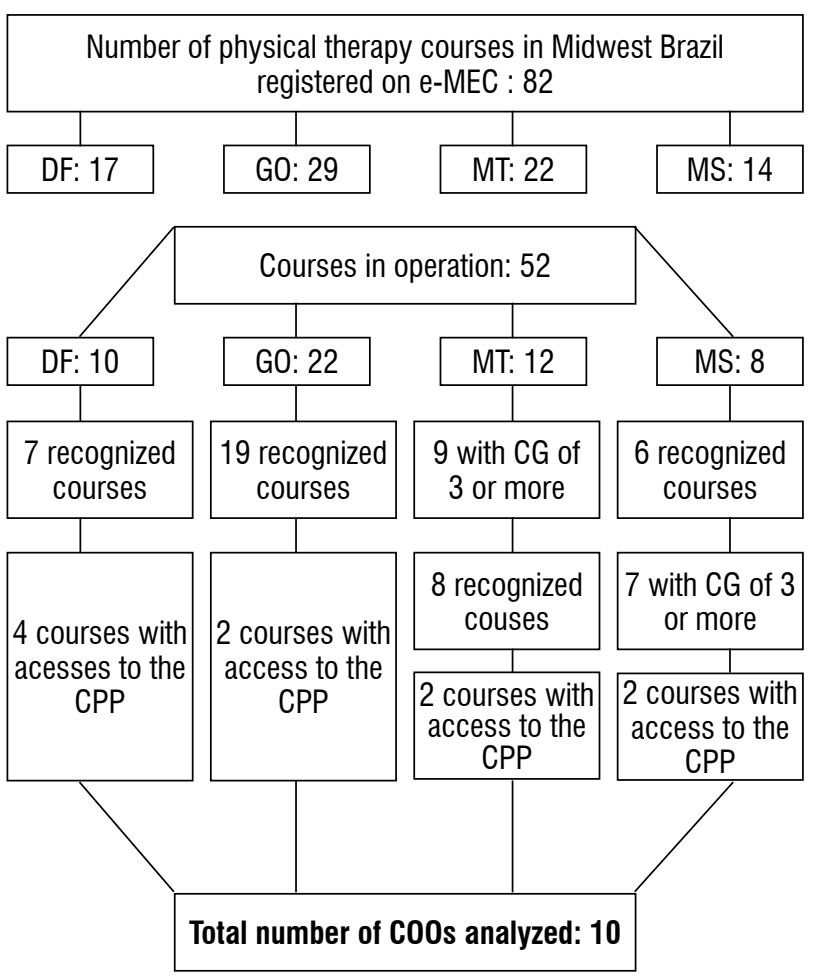

Figure 1 - Flowchart of the CPP selection process.

Table 2 presents the descriptive measures used to characterize the courses and CPPs according to the inclusion criteria for the study.
Table 2 - Descriptive measures used to characterize physical therapy courses in Midwest Brazil

\begin{tabular}{|c|c|c|c|}
\hline Variable & Minimum & Median & Maximum \\
\hline Year of the CPP & 2010 & 2014 & 2018 \\
\hline Course Grade & 3 & 3 & 5 \\
\hline Minimum class hours & 4,000 & 4,040 & 4,840 \\
\hline $\begin{array}{l}\text { Total number of } \\
\text { semesters }\end{array}$ & 8 & 9 & 10 \\
\hline $\begin{array}{l}\text { Annual places authorized } \\
\text { (in number of students) }\end{array}$ & 40 & 80 & 600 \\
\hline
\end{tabular}

Note: Authors' source; 2020.

\section{Categories analyzed}

Following comparison and tabulation of the data obtained, the final results were the same for both researchers in all the categories. Table 3 shows the number of courses that met or not the requirements of each category.

Table 3 - Number of courses in line with or not the requirements of each category

\begin{tabular}{lcc}
\hline Category & Yes & No \\
\hline ICF in the course objectives & 4 & 6 \\
$\begin{array}{l}\text { Caliber of graduates in line with NCGP } \\
\text { ICF in the curriculum outline of required courses }\end{array}$ & 6 & 4 \\
$\begin{array}{l}\text { ICF in the literature references of required } \\
\text { Courses }\end{array}$ & 2 & 8 \\
$\begin{array}{l}\text { CPP based on the biopsychosocial model } \\
\text { P. }\end{array}$ & 10 & - \\
\hline
\end{tabular}

Note: Authors' source; 2020.

Qualitative analysis

Qualitative analysis was applied to elucidate certain questions and make Table 3 easier to understand.

Excerpts from some of the CPPs studied are shown below in order to better understand the viewpoints of the researchers who analyzed them

\section{ICF in the course objectives}

CPPs 1, 5 and 6 included the concept of functioning, evident in the following excerpts:

"Ensure the integrality of care... that promote functioning ..." (CPP 1) 
"Check, assess and reassess parameters related to functioning..." (CPP 5)

"Train physical therapists equipped to provide conscious and critical care aimed at functioning..." (CPP 6) "Understanding ... a new way of creating interventions that target functional movement, focused on health conditions and not only disease" (CPP 10).

In the other CPPs, the course objectives did not contain references to the ICF or functioning.

Graduate profile in line with NCGP:

The graduate profile described in all the CPPs studied was based on NCGP, as shown in the excerpts below from CPPs 4, 5, 6 and 9:

“...aims to train professionals capable of understanding and respecting people... maintaining an inquisitive spirit... preventing disease... working in multidisciplinary teams... ensure diversified training".... (CPP 4)

"...Considering individuals as a morphofunctional, psychosocial and cultural complex...acting autonomously and multiprofessionally in prevention, promotion, protection and rehabilitation..." (CPP 5) "...graduates... should be generalists... with an emphasis on the SUS... Committed to human dignity... understanding the individual as a whole"... (CPP 6)

"...have solid general training... master the concepts... a reflective attitude and critical analysis skills... (CPP 9)

In the remaining CPPs, NCGP were directly cited as part of the graduate profile, with article 3 of the guidelines frequently found in whole or in part, as follows:

“...physical therapy graduates should have generalist, humanized training, be capable of critical reflection and working at all levels of health care... They should have a broad, global view, respecting the ethical/bioethical and culturing ethics of individuals... whether in terms of pathological, kinetic or functional changes and their psychic or organic repercussions, with a view to preserving, developing and restoring the integrity of organs, systems and function, including everything from a physical and functional diagnosis to selecting and executing the relevant physiotherapy interventions for each situation." (CPPs 1, 2, 3, 7, 8, 10).
Also with respect to the graduate profile, CPP1 states that:

"Physiotherapists should have an integrated perspective of the science and knowledge on which their profession is based, understanding that their actions... contribute to promoting human functioning. Functioning is conceived in line with the theoretical framework of the International Classification of Functioning. Disability and Health (ICF)" (CPP1).

Along the same lines, CPP 6 refers to the graduate profile as follows:

“...capable of carrying out the necessary activities... recognizing functioning and human movement as an object of study"... (CPP 6).

The ICF in the curriculum outline of required courses

The outline of six of the CPPs contained specific courses that addressed the ICF, as follows: "Functioning and Health" (CPP 1); "International Classification of Functioning, Disability and Health - General overview of the ICF" (CPP 4); "The Semiotics of Physiotherapy" (CPP 6); "Assistive Technology and Functioning according to the ICF" and "Deontology - Understanding Impairment, Functioning and Disability according to the ICF" (CPP 7 and 9); "Child and Adolescent Health I - The ICF as a Guide for Functional and Kinetic Assessment in Children and Adolescents" (CPP 10). It is important to note that Semiotics of Physiotherapy (CPP 6) was the only course whose title did not make reference to the ICF, mentioning it instead in the course content and description.

The ICF in the literature references of required courses

In the references of the required courses, the ICF was only cited [27] in CPPs 1 and 6, while in others $(4,7,9$ and 10), although the ICF was included in the curriculum outline of required courses, no specific references were identified to support student research and learning.

\section{CPP based on the biopsychosocial model}

According to the document analysis conducted by the researchers, all the CPPs were based on the 
biopsychosocial model. The parameter used for this category was the mention of biological, individual and social aspects that define this model. In this respect, article 5, paragraph 5 of the NCGP was found in all the CPPs examined, as demonstrated in the excerpt below:

“...contribute to maintaining the health, well-being and quality of life of people, families and the community, considering their ethical, political, social, economic, environmental and biological conditions" (CPPs 1-10)

Moreover, other sections of text also reinforced the tendency of CPPs to follow the biopsychosocial model:

“...physiotherapy training currently based on the medical model needs to be expanded..." (CPP 1)

"...always striving to maintain and recover the biopsychosocial integrity of the individual" (CPP 2);

"...a holistic view of the patient, identifying him/her as a human being" (CPP 4);

“...because healthcare professionals should not focus solely on disease and disregard the person as a whole..., "Considering the human being as a morphofunctional, psychosocial complex...";

"...resolve the problems experienced by the population, who generally exhibit a combination of biopsychosocial and environmental aspects" (CPP 5);

"...should recognize social reintegration as the final product of physical therapy, working proactively towards the social inclusion of patients" (CPP 6);

"...working within the biopsychosocial contextualization of the health-disease process..." (CPPs 7, 8 and 9); "Considering the wide range of clinical, scientific, philosophical, ethical, political, social and cultural issues"... (CPPs 3, 4 and 8);

"...bearing in mind that the responsibility of care does not end with the technical act...but with the resolution of the health problem on both an individual and collective level"... (CPPs 4, 5 and 8);

"...capable of identifying health needs...considering the health-disease-care process and its multiple dimensions", “...building a society that views man as the measure of all things";

"Understanding health as socially determined and human beings in their biological, psychological, social and cultural dimensions." (CPP 10).

\section{Discussion}

The aim of the present study was to assess CPPs by exploratory document analysis and determine whether they propose teaching and using the ICF in student training in undergraduate physical therapy courses in Midwest Brazil. Course pedagogical projects should adapt, optimize, enrich and supplement their curricula, and monitor them on an ongoing basis to allow for the necessary adjustments and improvements" [25]. Since the ICF was endorsed by the World Health Organization in 2001 [34] and the CPPs analyzed were from 2010 to 2018, some of these documents (CPPs 1, $4,6,7,9$ and 10) were adjusted to the ICF to comply with NCGF demands.

Article 5 of these guidelines states that: "Physiotherapy training should be conducted in line with the current healthcare system" [25]. Given that the Ministry of Health implemented the ICF within the SUS via Resolution 452 of 2012 [36], physiotherapy training should be based on the SUS setting and include the ICF. Resolution 370 of 2009 (COFFITO) recommends that higher education institutions (HEI) teach the ICF to undergraduate, graduate and outreach students [35]. It is important to underscore that six of the CPPs examined referred to the ICF, while the other four made no mention of it, indicating a possible gap between physiotherapy training and access to the ICF.

Another noteworthy fact is that seven of the ten CPPs assessed were from private institutions, which may reflect an incentive for the growth of higher education at the time via National Education Guidelines and Framework Law (LDB) no. 9.394 and the 2001-2010 National Education Plan (PNE) 2001-2010. These incentives resulted in the rapid and disorganized expansion of higher education, favoring the indiscriminate and unplanned creation of courses, particularly in the private sector $[13,14]$.

Given that physical therapy is based on functioning, one would expect this parameter to feature prominently in the category "The ICF in course objective", but this was only true for CPPs 1, 5, 6 and 10. Thus, it is important to emphasize that the training received in undergraduate courses will directly affect the future professional practices of these students [37]. The fact that the ICF was not included in the course objectives of some CPPs may therefore indicate a gap between this classification instrument and the outline of these 
objectives, which could contribute to the continued dominance of the biomedical model.

Paradoxically, the graduate profiles in all the CPPs analyzed were in line with NCGP, which prioritize professional training that considers the economic, social, environmental and biological factors [25] of the disease process, thus echoing the biopsychosocial model. It is important to underscore that the ICF was only referred to in the graduate profile of CPP1 as an instrument that supports functioning. As such, this CPP makes an important connection between the ICF and professional practice, indicating possible shortcomings in contextualization of the instrument and underuse in the remaining CPPs, as well as inconsistent application of the biopsychosocial model.

Another noteworthy point is that excerpts from NGCP were cited in the "Graduate profile is in line with NGCP" category, particularly article 3 [25], although these concepts do not necessarily translate into professional practice, as reported by Teixeira [44]. Given that functioning is the main indicator of rehabilitation [29], the critical, generalist and reflective graduate profile stipulated in NCGP [25] should include aspects related to functioning from the start of academic training [48] to ensure that students become agents of change [32, 49], making it important for CPPs to recommend both teaching and using the ICF.

Thus, by giving students the opportunity to use the ICF, course pedagogical projects could contribute to a future in which health is considered, practice and perceived multidimensionally.

However, for the "ICF in the curriculum outline of required courses" category, the instrument was cited by six CPPs $(1,4,6,7,9$ and 10), which may indicate that efforts are being made to include teaching the ICF in pedagogical projects, as reported by Ruaro [50]. Additionally, the ICF was cited in the literature references of required courses only in CPPs 1 and 6.

Given that these references allow students to improve their knowledge [51], and the curriculum outline included the ICF, it would be reasonable to expect this tool to be listed in the course references, which was not the case for 8 of the CPPs analyzed. These findings seem to confirm shortcomings in teaching the ICF as part of student training, possibly due to factors such as its complex application $[30,52]$ and the reluctance of professionals to accept the instrument [53].

It should be noted that resistance to using the ICF is not exclusive to physical therapy, but also occurs in other health-related courses $[49,54]$. Similarly, another study found that healthcare professionals generally have only superficial knowledge of the ICF and those who reported being familiar with it did not use its theoretical or coding framework [55]. Along the same lines, Ressler [56] confirmed his study hypothesis when he reported that the ICF was underused by physical therapists and the minimal knowledge of the instrument among physiotherapy students. Another investigation also found that poor understanding of the ICF occurred because the instrument was not covered in depth during undergraduate studies, highlighting the relevance of teaching and using its in physical therapy programs [57].

Comprehensive dissemination of the ICF in both the curriculum outline as well as research and outreach initiatives, combined with active methodologies, could increase professional awareness and application of the biopsychosocial model [56], representing a break from the paradigm. The difficulties identified in acceptance, adherence and applicability of the ICF mean that challenges remain to be overcome [30, 31, 52, 53, 58]. It is important to underscore that measuring health and living conditions in terms of functioning, as proposed by the ICF, is a naturally complex process $[30,59]$. This may result in resistance and disinterest, which prevents professionals from reaping the benefits of ICF application, culminating in their unwillingness to learn and use it. However, the root cause of this entire process may be the hegemony of the biomedical model, since professionals often fail to identify with the biopsychosocial approach of the ICF $[8,9,60]$, reflecting once again on their training in a paradigmatic cycle.

Paradoxically, in the "CPP based on the biopsychosocial model" category, the wording of all the CPPs echoed this model, which, when combined with the contextualization of the ICF in some CPPs, may indicate an initial attempt to teach this classification framework. As such, coherently teaching and applying the ICF and its inherent biopsychosocial model in both the classroom and during internships $[45,54,56]$ may be an important first step in changing professional practices historically based on the biomedical model of health $[20,61]$.

\section{Conclusion}

Exploratory document analysis of course pedagogical projects (CPPs) identified the ICF in several CPPs, indicating important and favorable changes in terms of including functioning in student training, which 
does not preclude the need for a broader approach to teaching and using this classification framework in the remaining CPPs in order to provide training within a biopsychosocial context.

The present study does not exhaust all the research possibilities of the topic; indeed, the difficulties encountered in accessing the CPPs clearly demonstrate the need for additional investigation to ensure that these course frameworks are more in keeping with the current health needs of the Brazilian population.

\section{Acknowledgments}

This study received funding from the Coordination for the Improvement of Higher Education Personnel (CAPES) - funding code 001.

\section{References}

1. Rebelatto JR, Botomé SP. Fisioterapia no Brasil: fundamentos para uma ação preventiva e perspectivas profissionais. $2^{\text {nd }}$ ed. São Paulo: Manole; 1999.

2. Neumann DA. Polio: its impact on the people of the United States and emerging profession of Physical Therapy. J Orthop Sports Phys Ther. 2004;34(8):479-92.

3. Rodrigues RM. A fisioterapia no contexto da política de saúde no Brasil: aproximações e desafios. Perspectivas Online. 2008;2(8):104-9.

4. Barros FBM. Poliomielite, filantropia e fisioterapia: o nascimento da profissão de fisioterapeuta no Rio de Janeiro dos anos 1950. Cienc Saude Coletiva. 2008;13(3):941-54.

5. Nogueira RP, Risi JB. As condições de saúde no Brasil. In: Finkelman J, org. Caminhos da Saúde Pública no Brasil. Rio de Janeiro: Fiocruz; 2002. p. 119-234.

6. Reis J. O sorriso de Hipócrates: a integração biopsicossocial dos processos de saúde e doença. Lisboa: Vega; 1999. Chapter: Concepções médicas: da antiguidade ao modelo biomédico actual; p. 15-52.

7. Silva ID, Silveira MFA. A humanização e a formação do profissional em Fisioterapia. Cien Saude Coletiva. 2011;16(suppl 1):1535-46.
8. Shiwa SR, Schmitt ACB, João SMA. O fisioterapeuta do estado de São Paulo. Fisioter Pesqui. 2016;23(3):301-10.

9. Bispo Jr JP. Formação em fisioterapia no Brasil: reflexões sobre a expansão do ensino e modelos de formação. Hist Cien Saude. 2009;16(3):655-68.

10. Naves CR, Brick VS. Análise quantitativa e qualitativa do nível de conhecimento dos alunos do curso de Fisioterapia sobre a atuação do fisioterapeuta em saúde pública. Cien Saude Coletiva. 2011;16(suppl 1):1525-34.

11. Nascimento MC, Sampaio RF, Salmela JH, Mancini MC, Figueiredo IM. A profissionalização da fisioterapia em Minas Gerais. Rev Bras Fisioter. 2006;10(2):241-7.

12. Freitas MS. A atenção básica como campo de atuação da Fisioterapia no Brasil: as Diretrizes Curriculares ressignificando a prática profissional [dissertation]. Rio de Janeiro: Universidade do Estado do Rio de Janeiro; 2006.

13. Matsumara ESS, Castro LSF, Kietzer KS. Panorama dos cursos de graduação em Fisioterapia no Brasil. Riga Letónia: Novas Edições Acadêmicas; 2018. p. 441.

14. Goes AB, Araújo FRO, Marques AP, Schmitt ACB. Overview of physical therapy graduation courses in Brazil: current scenario. Fisiot Mov. 2017;30(4):661-9.

15. Marques AP, Sanches ES. Origem e evolução da Fisioterapia: aspectos históricos e legais. Rev Fisioter USP. 1994;1(1):5-10.

16. Brasil. Decreto-lei n. 938, de 13 de outubro de 1969. Provê sobre as profissões de fisioterapeuta e terapeuta ocupacional e dá outras providências. Brasília, DF: Presidência da República.

17. Mariotti MC, Bernardelli RS, Nickel R, Zeghbi AA, Teixeira MLV, Costa Filho RM. Características profissionais, de formação e distribuição geográfica dos fisioterapeutas do Paraná - Brasil. Fisioter Pesqui. 2017;24(3):295-302.

18. Brasil. Lei 6316 de 17 de dezembro de 1975. Cria o Conselho Federal e os Conselhos Regionais de Fisioterapia e Terapia Ocupacional e dá outras providências. Brasília, DF: Diário Oficial da União. 1975 Dec 18.

19. Ceccim RB. Invenção da saúde coletiva e do controle social em saúde no Brasil: nova educação na saúde e novos contornos e potencialidades à cidadania. REU. 2007;33(1):29-48.

20. DeMarco MA. A face humana da medicina - do modelo biomédico ao modelo biopsicossocial. São Paulo: Casa do Psicólogo; 2003. 
21. Pereira TTSO, Barros MNS, Augusto MCNA. O cuidado em saúde: o paradigma biopsicossocial e a subjetividade em foco. Mental. 2011;9(17):523-36.

22. Andrade TL, Queiroz E, Martins EF. Desafios da formação profissional para a assistência a pacientes em internação domiciliar e seus cuidadores. In: Abbad GS, Parreira CMSF, Pinho DLM, Queiroz E (Eds.). Ensino na saúde no Brasil: desafios para a formação profissional e qualificação para o trabalho. Brasília, DF: Juruá; 2016. p. 227-264.

23. Costa JRC. Perícia biopsicossocial: reflexões para a efetivação dos direitos sociais previdenciários por incapacidade laboral a partir de um novo paradigma. Juris. 2014;21:119-48.

24. Santos JLF, Westphal MF. Práticas emergentes de um novo paradigma de saúde: o papel da universidade. Estud Av. 1999;13(35):71-88.

25. Brasil. Ministério da Educação. Conselho Nacional de Educação. Câmara de Educação Superior. Resolução CNE/CES 4 de 19 de fevereiro de 2002. Institui Diretrizes Curriculares Nacionais do curso de graduação em Fisioterapia. Brasília, DF: Diário Oficial da União. 2002 Feb 19.

26. Fernandes JD, Rebouças LC. Uma década de Diretrizes Curriculares Nacionais para a Graduação em Enfermagem: avanços e desafios. Rev Bras Enferm. 2013;66(spe):95-101.

27. OMS, org. CIF: Classificação Internacional de Funcionalidade, Incapacidade e Saúde. São Paulo: EdUSP; 2015.

28. Seger $W$. The rediscovery of the social side of medicine: philosophy and value of the International Classification of Functioning, Disability and Health (ICF). Eletron Physician. 2018;10(3):6426-9.

29. Stucki G, Bickenbach J. Functioning: The third health indicator in the health system and the key indicator for rehabilitation. Eur J Phys Rehabil Med. 2017;53(1):134-8.

30. Stucki G, Zampolini M, Juocevicius A, Negrini S, Christodoulou N. Practice, Science and governance in interaction: European effort for the system-wide implementation of the International Classification of Functioning, Disability and Health (ICF) in Physical and Rehabilitation Medicine. Eur J Phys Rehabil Med. 2017;53(2):299-307.

31. Buchalla CM. A Classificação Internacional de Funcionalidade, Incapacidade e Saúde. Acta Fisiatrica. 2003;10(1):29-31.
32. Scholten I, Ross K, Bickford J. "A way to think of the client holistically": factors influencing students ICF regard and uptake. MedEdPublish. 2019;8(1):1-18

33. Farias N, Buchalla CM. A Classificação Internacional de Funcionalidade, Incapacidade e Saúde da Organização Mundial de Saúde: conceitos, usos e perspectivas. Rev Bras Epidemiol. 2005;8(2):187-93.

34. OMS. WHA-54.21 - Fifty-Fourth World Health Assembly. International classification of functioning, disability and health. 22 May 2001 [cited 2018 Jul 01]. Available from: https://tinyurl.com/yc36nxh3

35. Brasil. Conselho Federal de Fisioterapia e Terapia Ocupacional. Resolução 370 de 6 de novembro de 2009. Dispõe sobre a adoção da Classificação Internacional de Funcionalidade Incapacidade e Saúde (CIF) da Organização Mundial de Saúde, por fisioterapeutas e terapeutas ocupacionais [cited 2018 Jul 01]. Available from: https:// tinyurl.com/yasrheck

36. Brasil. Ministério da Saúde. Resolução 452 de 10 de maio de 2012. Institui o uso da Classificação Internacional de Funcionalidade Incapacidade e Saúde no SUS [cited 2018 Jul 1]. Available from: https://tinyurl.com/y8reqaud

37. Ceccim RB, Feuerwerker LCM. Mudança na graduação das profissões de saúde sob o eixo da integralidade. Cad Saude Publica. 2004;20(5):1400-10.

38. Minayo MCS. 0 desafio do conhecimento: pesquisa qualitativa em saúde. $8^{\text {th }}$ ed. São Paulo: Hucitec; 2004.

39. Bardin L. Análise de conteúdo. $3^{\text {rd }}$ ed. Portugal: Edições 70; 2004.

40. Creswell JW. Projeto de pesquisa: método qualitativo, quantitativo e misto. $2^{\text {nd }}$ ed. Porto Alegre: Artmed; 2007.

41. Driessnack M, Sousa VD, Mendes IAC. Revisão dos desenhos de pesquisa relevantes para a enfermagem: parte 3: métodos mistos e múltiplos. Rev Latino-Am Enfermagem. 2007;15(5).

42. Kripka RML, Sheller M, Bonotto D. Pesquisa documental na pesquisa qualitativa: conceitos e caracterização. Rev Investigaciones Unad. 2015;14(2):55-73.

43. Brasil. Ministério da Educação e Ministério da Saúde. A aderência dos cursos de graduação em Enfermagem, Medicina e Odontologia às Diretrizes Curriculares Nacionais. Brasília: Ministério da Saúde; 2006. 
44. Teixeira RC. Aderência dos cursos de fisioterapia da região Norte às Diretrizes Curriculares Nacionais. Fisioter Mov. 2012;25(1):47-54.

45. Almeida, SM, Marães VRFS, Escalda PMF. Integralidade na formação do Fisioterapeuta no Distrito Federal: uma leitura dos projetos pedagógicos de curso. In: Abbad GS, Parreira CMSF, Pinho DLM, Queiroz E (Eds.). Ensino na saúde no Brasil: desafios para a formação profissional e qualificação para o trabalho. Brasília, DF: Juruá; 2016. p. 99-112.

46. Borges KP. Competências para formação do fisioterapeuta no âmbito das Diretrizes Curriculares Nacionais e promoção da saúde. Saude Pesqui. 2018;11(2):347-58.

47. Braga ARCSL. Classificação Internacional de Funcionalidade, Incapacidade e Saúde (CIF) nos cursos de graduação em Terapia Ocupacional [master's thesis]. Brasília, DF: Universidade de Brasília; 2013.

48. Marães VRFS, Martins EF, Cipriano Jr G, Acevedo AC, Pinho DLM. Projeto Pedagógico do curso de Fisioterapia da Universidade de Brasília. Fisioter Mov. 2010;23(2):311-21.

49. Bornbaum CC, Day AM, Izaryk K, Morrison SJ, Ravenek MJ, Sleeth LE, et al. Exploring use of the ICF in health education. Disabil Rehabil. 2015;37(2):179-86.

50. Ruaro JA, Ruaro MB, Souza DE, Fréz AR, Guerra RO. Panorama da utilização da CIF no Brasil - uma década de história. Rev Bras Fisioter. 2012;16(6):454-62.

51. Galvão MCB. O levantamento bibliográfico e a pesquisa científica. [cited 2019 Mar 30]. Available from: https:// tinyurl.com/wtevl9e

52. Sabino GS, Coelho CM, Sampaio RF. Utilização da Classificação Internacional de Funcionalidade, Incapacidade e Saúde na avaliação fisioterapêutica de Indivíduos com problemas musculoesqueléticos nos membros inferiores e região lombar. Acta Fisiatrica. 2008;15(1):24-30.
53. Cieza A, Brockow T, Ewert T, Amman E, Kollerits B, Chatterji $\mathrm{S}$, et al. Linking health-status measurements to the International Classification of Functioning, Disability and Health. J Rehabil Med. 2002;34(5):205-10.

54. Braga ARCSL, Marães VRFS. Funcionalidade nos projetos pedagógicos dos cursos de graduação em Terapia Ocupacional. In: Abbad GS, Parreira CMSF, Pinho DLM, Queiroz E (Eds.). Ensino na saúde no Brasil: desafios para a formação profissional e qualificação para o trabalho. Brasília, DF: Juruá; 2016. p. 77-98.

55. Andrade LEL, Oliveira NPD, Ruaro JA, Barbosa IR, Dantas DS. Avaliação do nível de conhecimento e aplicabilidade da Classificação Internacional de Funcionalidade, Incapacidade e Saúde. Saude Debate. 2017;41(114):812-23.

56. Ressler S. O uso prático da Classificação Internacional de Funcionalidade, Incapacidade e Saúde em Fisioterapia [master's thesis]. Criciúma (Brazil): Universidade do Extremo Sul Catarinense; 2017.

57. Belmonte LM, Chiaradia LCN, Belmonte LAO. CIF nos cursos de graduação da grande Florianópolis. Rev CIF Brasil. 2015;2(2):11-24.

58. Wenzel TR, Morfeld M. The bio-psycho-social model and the International Classification of Functioning, Disability and Health: examples of using the model, its parts and the items. Bundesgesundheitsblatt Gesundheitsforschung Gesundheitsschutz. 2016;59(9):1125-32.

59. Araújo ES. CIF: Uma discussão sobre linearidade no Modelo Biopsicossocial. Rev Fisioter S Fun. 2013;2(1):6-13.

60. Pereira SCM. Contributo para a implementação da CIF para a identificação de ganhos em saúde nas doenças crónicas [master's thesis]. Lisboa: Universidade de Nova Lisboa; 2008.

61. Stallinga HA, Dijkstra PU, Napel HT, Roodbol G, Peters JWB, Heerkens YF, et al. Perceived usefulness of the International Classification of Functioning, Disability and Health (ICF) increases after a short training: a randomized controlled trial in master of advanced nursing practice students. Nurse Educ Pract. 2018;33:55-62.

Received: 07/07/2019

Recebido: 07/07/2019

Approved: 03/23/2020

Aprovado: 23/03/2020 